\title{
ANALISIS PAJAK PERTAMBAHAN NILAI PADA PERUSAHAAN ASIA GRAHA SUKSES MANDIRI TULUNGAGUNG
}

\author{
Firman Alifianto, Gusmik Adil, Anggya Arvianti,Aditya Dwi Chrisdianto
}

\begin{abstract}
ABSTRAK
Penelitian yang kami lakukan disini dilatar belakangi karena berbagai masalah yang berhubungan dengan perdagangan bisnis dan pengembangan SDM. Penanganan masalah yang berkaitan dengan hal tersebut harus perlu didukung juga dengan adanya sumber-sumber daya yang kualitasnya pun perlu ditingkatkan secara terus-menerus. Penelitian ini bertujuan untuk mengetahui pelaksanaan pengembangan sumber daya manusia yang dilakukan oleh perusahaan ini serta pegawainya dari tahun 1997 melalui program pelatihan minimal selama 1 bulan atau maksimal selama 3 bulan. Penelitian ini merupakan penelitian deskriptif kualitatif yang dilaksanakan di Kota Tulungagung. Penulis menggunakan teknik Purposive Sampling dengan menunjuk dari beberapa informan yang lebih memiliki pemahaman lebih mendalam dari permasalahan yang diteliti. Hasil dari penelitian yang kami peroleh dari riset adalah berupa data dari hasil wawancara bahwa Pemahaman dan kesadaran masyarakat maupun perusahaan yang melakukan transaksi pajak dalam pemenuhan kewajiban pajak penghasilan masih kurang yang mana meskipun mengetahui bahwa penghasilan yang diperoleh melalui transaksi pajak merupakan objek pajak, tetap saja baik masyarakat dan perusahaan tersebut tidak mendaftarkan diri untuk mendapatkan NPWP, melaksanakan kewajiban pemenuhan pajaknya dengan tidak memasukkan penghasilan dari transaksi pajak yang dilakukan ke dalam SPT tahunannya. Bahkan ada perusahaan yang tidak mengetahui transaksi pajak yang dilakukannya itu dikenai pajak penghasilan.

Wajib pajak sendiri selayaknya memahami pentingnya pemenuhan pajak penghasilannya, karena pajak yang dibayarkan oleh wajib pajak akan digunakan sebagai biaya bagi pembangunan nasional yag dilakukan oleh pemerintah, maka wajib pajak harus memenuhi pajak dalam setiap tahun
\end{abstract}


Kata Kunci : Pelaksanaan, Perdagangan, Pengembangan, Pelatihan, dan Sumber Daya Manusia (SDM).

\section{PENDAHULUAN \\ LATAR BELAKANG}

Perusahaan Asia Graha Sukses Mandiri merupakan sebuah perusahaan di Tulungagung yang bergerak di bidang perdagangan umum dan pengembangan sumber daya manusia. Perusahaan yang bergerak dalam bidang jasa ini merupakan salah satu darisekian jenis perusahaan jasa yang terkena pajak pertambahan nilai, yang mana pajak ini merupakan pajak yang dibebankan kepada transaksi jual-beli atas barang ataupun jasa. Penelitian ini dilakukan demi mengetahui informasi terkait bagaiman perusahaan menyikapi pajak pertambahan nilai dari jasa yang di hasilkan oleh perusahaan tersebut.

Dari latar belakang yang dijelaskan, maka rumusan masalah yang dapat diambil untuk dibahas ada empat yaitu: bagaimana perusahaan menyikapi adanya pajak pertambahan nilai, bagaimana sikap perusahaan dalam kegiatan pembayaran pajak, apakah dampak adanya pajak pertambahan nilai untuk perusahaan, bagaimana mekanisme pembayaran pajak pertambahan nilai oleh perusahaan.

Dari rumusan masalah tersebut, tujuan yang ingin dicapai yaitu: mengetahui tentang adanya pajak pertambahan nilai, memahami tingkat kedisiplinan perusahaan dalam pembayaran pajak pertambahan nilai,mengetahui apa saja dampak yang terjadi perusahaan sehubungan dengan adanya pajak pertambahan nilai, memahami bagaimanakah mekanisme pembayaran pajak pertambahan nilai yang dilakukan perusahaan. 


\section{LANDASAN TEORI}

\section{PAJAK PERTAMBAHAN NILAI}

\section{A. Pengertian Pajak Pertambahan Nilai}

Apa itu PPN? Pajak Pertambahan Nilai atau PPN adalah pungutan yang dibebankan atas transaksi jual-beli barang dan jasa yang dilakukan oleh wajib pajak pribadi atau wajib pajak badan yang telah menjadi Pengusaha Kena Pajak (PKP).

Jadi, yang berkewajiban memungut, menyetor dan melaporkan PPN adalah para Pedagang/Penjual. Namun, pihak yang berkewajiban membayar PPN adalah Konsumen Akhir.

PPN atau Pajak Pertambahan Nilai dikenakan dan disetorkan oleh pengusaha atau perusahaan yang telah dikukuhkan sebagai Pengusaha Kena Pajak (PKP).

Menurut Supramono $(2009 ; 125)$ pajak pertambahan nilai merupakan pajak yang dikenakan atas konsumsi di dalam negeri, baik konsumsi BKP maupun JKP. ${ }^{1}$

Berdasarkan penjelasan UU Nomor 42 tahun 2009 tentang perubahan ketiga atas UU Nomor 8 tahun 1983 tentang pajak pertambahan nilai dan jasa dan pajak penjualan atas barang mewah, pada bagian umum, pajak pertambahan niali adalah pajak konsumsi barang dan jasa di daerah pabean yang dikenakan secara bertingkat disetiap jalur produksi dan ditribusi.

Menurut Waluyo (2011:9) menyatakan bahwa pajak pertambahan nilai merupakan pajak yang dikenakan atas konsumsi di dalam daerah pabean, baik konsumsi barang maupun konsumsi jasa. $^{2}$

Mardiasmo (2009:269) menatakan bahwa apabila dilihat dari sejarahnya, pajak pertambahan nilai merupakan pengganti dari pajak penjualan. Alasan pengertian ini karena pajak penjualan dirasa sudah tidak lagi memadai untuk menampung kegiatan masyarakat dan belum mencapai sasaran kebutuhan pembangunan, antara lain untuk meningkatkan penerimaan negara, mendorong ekspor dan pemerataan pembebanan pajak. ${ }^{3}$

\section{Mardiasmo, pajak penjualan mempunyai kelemahan, yaitu :}

1. Adanya pajak ganda

2. Macam-macam tarif, sehingga menimbulkan kesulitan

3. Tidak mendorong ekspor

4. Belum dapat mengatasi penyelundupan

\section{Sedangkan pajak pertambahan nilai (PPN) mempunyai kelebihan, yaitu :}

1. Menghilangkan pajak ganda

2. Menggunakan tarif tunggal sehingga mudah pelaksanaannya

3. Netral dalam persaingan dalam negeri, perdagangan nasional. Netral pola konsumsi dalam mendorong ekspor.

\footnotetext{
${ }^{1}$ Irfan Fatoni and Indah Dewi Nurhayati, 'Jurnal Manajemen Dan Akuntansi Volume 3, Nomor 2, Agustus 2014', 3.April (2014), 1-14.

${ }^{2}$ Fatoni and Nurhayati.

${ }^{3}$ Fatoni and Nurhayati.
} 


\section{B. Dasar Hukum Pajak Pertambahan Nilai (PPN)}

Berlakunya UU No. 42 Tahun 2009 tentang perubahan ketiga atas UU No. 08 Tahun 1983 kemudian diubah menjadi UU No. 11 Tahun 1994, dan yang terakhir diubah lagi dengan UU No. 18 Tahun 2000 tentang pajak pertambahan nilai (PPN) barang dan jasa dan pajak penjualan atas barang mewah. Aturan pelaksanaan terakhir diatur pada UU No. 42 Tahun 2009.

Dengan UU No. 08 Tahun 1983 dipungut pajak pertambahan nilai dan penjualan atas barang mewah. Perbedaan utama pajak pertambahan nilai dari peredaran dan pajak penjualan 1951 adalah tidak adanya unsur pajak berganda.

UU yang mengatur pengenaan pajak pertambahan nilai (PPN) barang dan jasa serta pajak penjualan atas barang mewah adalah UU No.08 Tahun 1983 kedua pajak ini merupakan sebagai pajak yang dipungut atas konsumsi dalam negeri. Khususnya terhadap penjualan atau penyerahan barang mewah selain dikenakan pajak pertambahan nilai juga dikenalkan pajak penjualan atas barang mewah.

Dalam UU ditemukan bahwa UU PPN diberlakukan 1 Juli tahun 1984, dengan peraturan pemerintah pengganti UU (PERPEU) No. 1 Tahun 1984. Mulainya berlaku UU PPN ditangguhkan sampai tanggal 1 Juli 1986, dan ditetapkan peraturan pemerintah. ${ }^{4}$

\section{B. Mekanisme Pemungutan Pajak Pertambahan Nilai (PPN)}

Mekanisme pemungutan PPN sesuai dengan PMK Nomor 85/PMK.03/2012 tanggal 06 Juni 2012 yang berlaku efektif mulai 1 Juli 2012 adalah: $^{5}$

1. Mekanisme pemungutan PPN yang pertama dan wajib adalah rekanan wajib membuat faktur pajak dan surat setoran pajak (SSP) atas setiap penyerahan BKP dan/atau JKP kepada BUMN.

2. Mekanisme pemungutan PPN yang kedua adalah faktur pajak sebagaimana dimaksud pada angka 1 dibuat sesuai dengan ketentuan di bidang perpajakan.

3. Ketiga adalah SSP sebagaimana dimaksud pada angka 1 diisi dengan membubuhkan NPWP serta identitas rekanan, tetapi penandatanganan SSP dilakukan oleh BUMN sebagai penyetor atas nama rekanan.

4. Keempat adalah dalam hal penyerahan BKP selain terutang PPN juga terutang PPnBM maka rekanan harus mencantumkan juga jumlah PPnBM yang terutang pada faktur pajak.

5. Kelima adalah faktur pajak dibuat dalam rangkap 3 dengan peruntukkan sebagai berikut : lembar kesatu untuk BUMN, lembar kedua untuk rekanan, dan lembar ketiga untuk BUMN yang dilampirkan pada SPT Masa PPN bagi pemungut PPN.

\footnotetext{
${ }^{4}$ Kezia Rafinzka, 'Pasal 4 UU PPN', Angewandte Chemie International Edition, 6(11), 951-952., 42, 1967, 3-4 <https://www.online-pajak.com/tentang-ppn-efaktur/pasal-4-uu-ppn>.

${ }^{5}$ Rachmad Gesah Mukti Prabowo, 'MEKANISME PPN DAN PPnBM', 2019

<https://doi.org/10.31227/osf.io/shqmg>.
} 
6. Keenam adalah SSP sebagaimana dimaksud pada angka 1 dibuat dalam rangkap 5 dengan peruntukkan sebagai berikut : lembar kesatu untuk rekanan, lembar kedua untuk KPPN melalui Bank Persepsi atau Kantor Pos, lembar ketiga untuk rekanan yang dilampirkan pada SPT Masa PPN, lembar keempat untuk Bank Persepsi atau Kantor Pos, dan lembar kelima untuk BUMN yang dilampirkan pada SPT Masa PPN bagi Pemungut PPN.

7. Mekanisme Pemungutan PPN yang terakhir adalah faktur Pajak dan SSP merupakan bukti pemungutan dan penyetoran PPN atau PPN dan PPnBM.(Prabowo, 2016)

\section{Subjek Dan Objek Pajak Pertambahan Nilai (PPN)}

Menurut Resmi ${ }^{6}$ pajak pertambahan nilai merupakan pajak tidak langsung, artinya pajak yamg pada akhirnya dapat dibebankan atau dialihkan kepada orang lain atau pihak ketiga. Pihak-pihak yamg mempunyai kewajiban memungut, menyetor, dan melaporkan PPN terdiri atas:

Pengusaha Kena Pajak (PKP) yang melakukan penyerahan barang kena pajak atau jasa kena pajak didalam daerah pabean dan melakukan ekspor barang kena pajak berwujud atau tidak berwujud atau jasa kena pajak. Pengusaha Kecil yang memilih untuk dikukuhkan sebagai pengusaha kena pajak (PKP).

\section{OBJEK PAJAK PERTAMBAHAN NILAI}

Menurut Helmy (2005:63) Obyek Pajak Pertambahan Nilai dikenakan sebagai berikut : ${ }^{7}$

1) Penyerahan Barang Kena Pajak di dalam daerah pabean yang dilakukan pengusaha. Jurnal Manajemen dan Akuntansi Volume 1, Nomor 3, Desember 201234 Analisis Perhitungan Pajak

Novi Darmayanti) Penyerahan barang yang dikenekan pajak harus memenuhi syarat-syarat sebagai berikut :

1) Barang berwujud yang diserahkan merupakan Barang Kena Pajak,

2) Barang tidak berwujud yang diserahkan merupakan Barang Kena Pajak tidak berwujud,

3) Penyerahan dilakukan di dalam daerah pabean, dan

4) Penyerahan dilakukan dalam rangka kegiatan usaha atau kegiatan

a). Impor Barang Bena Pajak.

b). Penyerahan Barang Kena Pajak di dalam daerah pabean yang dilakukan oleh

Pengusaha Penyerahan Jasa yang terutang pajak harus memenuhi syarat-syarat sebagai berikut:

1) Jasa yang diserahkan merupakan Jasa Kena Pajak,

2) Penyerahan dilakukan didalam daerah pabean, dan

3) Penyerahan dilakukan dalam kegiata usaha atau pekerjaannya.

c). Pemanfaatan Barang Kena Pajak tidak berwujud dari luar daerah pabean di dalam daerah pebean

d). Pemanfaatan Jasa Kena Pajak dari luar daerah pabean di dalam daerah pabean.

e). Ekspor Barang Kena Pajak oleh Pengusaha Kena Pajak.

f). Kegiatan membangun sendiri yang tidak dilakukan dalam kegiatan usaha atau pekerjaan oleh orang pribadi atau badan.

g). Panyerahan aktiva oleh Pengusaha Kena Pajak yang menurut tujuan semula aktiva

\footnotetext{
${ }^{6}$ Brotodiharjo, 'Perhitungan PPn', Wandha Mar.8 (1991).

${ }^{7}$ Fatoni and Nurhayati.
} 
tersebut tidak untuk diperjual belikan, sepanjang Pajak Pertambahan Nilai yang dibayar pada saat perolehannya dapat dikreditkan.

\section{Tarif Pajak Pertambahan Nilai menurut ketentuan Undang-undang RI Tahun 2000 pasal 7 adalah :}

a). Tarif Pajak Pertambahan Nilai adalah $10 \%$.

b). Tarif Pajak Pertambahan Nilai atas ekspor barang kena pajak adalah 0\% (nol persen).

c). Dengan peraturan pemerintah tarif pajak dapat diubah serendah-rendahnya 5\% (lima persen) dan setinggi-tingginya $15 \%$.

d). Pajak Pertambahan Nilai untuk pabrikan yaitu $10 \%$ untuk perhitungan pajak keluarannya.

\section{Perhitungan Pajak Pertambahan Nilai}

Besarnya Pajak Pertambahan Nilai (PPN) dapat dihitung dengan selisih antara pajak yang telah dipungut pada saat penjualan atau penyerahan suatu barang atau jasa kena pajak. Penerimaan jasa kena pajak atau import barang kena pajak (pajak masukan). Apabila dalam suatu masa pajak, pajak keluaran lebih besar dari pada pajak masukkan, maka selisihnya merupakan Pajak Pertambahan Nilai (PPN) yang harus dibayar oleh Pengusaha Kena Pajak. Apabila dalam suatu masa pajak, pajak masukkan yang dapat dikreditkan lebih besar dari pajak keluaran, maka selisihnya merupakan kelebihan pajak yang dapat dikompensasikan pada masa pajak berikutnya.

\section{Subyek Pajak Pertambahan Nilai}

Subyek pajak adalah mereka yang menjadi penanggung jawab atas hutang pajak yang bertanggung jawab atas penyetoran pajak ke kas Negara berdasarkan Undangundang No. 18 Tahun 2000 adalah : ${ }^{8}$

a.) Pengusaha yang menurut Undang-undang harus dikukuhkan menjadi Pengusaha Kena Pajak (PKP) pengusaha atau wajib pajak yang otomatis adalah:

1) Pabrikan atau produsen termasuk pengusaha real estate/ industrial estate/ developer atau pengusaha yang menghasilkan barang kena pajak.

2) Pengusaha yang mengimpor barang kena pajak. I

3) Pengusaha yang mempunyai hubungan istimewa dengan pabrikan atau importer.

4) Agen utama dan penyaluran utama dari pabrikan atau importer.

5) Pemegang hak patent dan merk dagang dari barang kena pajak.

6) Pemborong/ kontraktor/ subkontraktor bangunan dan harta tetap lainnya

7) Pengusaha yang tidak termasuk ruang lingkup pengenaan pajak akan tetapi menyatakan memilih untuk dikukuhkan menjadi Pengusaha Kena Pajak (PKP) ialah :

1) Eksportir

2) Pedagang yang menjual Barang Kena Pajak (BKP).

\footnotetext{
${ }^{8}$ Fatoni and Nurhayati.
} 


\section{BARANG KENA PAJAK DAN JASA KENA PAJAK}

\section{Barang Kena Pajak (BKP)}

Menurut UU No. 42 tahun 2009 pasal 1(3) baran kena pajak adalah barang berwujud yang menurut sifat atau hukumnya dapat berupa barang bergerak atau barang tidak bergerak dan barang tidak berwujud yang dikenakan pajak berdasarkan UU.

Menurut Mardiasmo (2008:274) BKP adalah barang berwujud yang menurut sufat atau hukumnya dapat berupa barang bergerak atau barang tidak bergerak, dan barang tidak berwujud yang dikenakan pajak berdasarkan UU PPN.

Menurut Waluyo (2011:12) BKP adalah barang berwujud yang menurut sifat atau hukumnya dapat berupa barang bergerak atau barang tidak bergerak dan barang tidak berwujud yang dikenai pajak berdasarkan UU PPN dan PPnBM.

\section{E. Jasa Kena Pajak (JKP)}

Menurut UU No. 18 tahun 2000 dan No. 42 tahun 2009 pasal 1(6) PKP adalah setiap kegiatan pelayanan berdasarkan suatu perikatan atau perbuatan hokum yang menyebabkan suatu barang atau fasilitas atau memberi kemudahan atau hak tersedia untuk dipakai, termasuk jasa yang dilakukan untuk menghasilkan barang karena pesanan dan bahan dan petunjuk pemesan.

Suhartono dan Ilyas (2010:15) menyatakan bahwa dalam UU PPN No. 42 tahun 2009 menjelaskan bahwa pengusaha yang melakukan penyerahan BKP atau penyerahan JKP yamg tergolong pengusaha tidak diwajibkan untuk dikukuhkan sebagai PKP, kecuali pengusaha kecil tersebut memilih untuk dikukuhkan sebagai PKP.

\section{PENGECUALIAN BARANG KENA PAJAK DAN JASA KENA PAJAK}

\section{F. Pengecualian Barang Kena Pajak (BKP)}

Pada dasarnya semua barang adalah barang kena pajak, kecuali UU menetapkan sebaliknya. Jenis barang yang tidak dikenakan PPN ditetapkan dengan peraturan pemerintah berdasarkan atas kelompk-kelompok barang sebagai berikut:

a. Barang hasil pertambangan, penggalian, dan pengeboran, yang diambil langsung dari sumbernya seperti: minyak tanah, gas bumi, batu bara dll.

b. Barang-barang kebutuhan pokok yang sangat dibutuhkan oleh banyak rakyat seperti: beras, gabah, jagung, sagu, buah-buahan, sayur-sayuran dll.

c. Makanan dan minuman yang disajikan di hotel, restoran, rumah makan, warung dan sejenisnya meliputi makanan dan minuman baik yang dikonsumsi ditempat maupun tidak.

d. Uang, emas batangan, dan surat-surat berharga (saham, obligasi). 


\section{G. Pengecualian Jasa Kena Pajak (JKP)}

Pada dasarnya semua jasa dikenakan pajak, kecuali yamg ditentukan lain oleh UU PPN pada UU No. 42 tahun 2009, menurut Mardiasmo (2008:275) kelompk jasa yang tidak dikenakan pajak pertambahan nilai adalah jasa pelayanan kesehatan medis, jasa pelayanan social, jasa pengiriman surat dengan perangko, jasa keuangan, jasa asuransi dll. 


\section{METODE PENELITIAN}

\section{DESAIN PENELITIAN}

Penelitian ini ditujukan untuk mengetahui tentang bagaimana perusahaan menyikapi adanya pajak pertambahan nilai yang mengenai produk yang dihasilkan oleh perusahaan. Penelitian ini menggunakan metode deskriptif kualitatif yang merupakan desain penelitian yang yang bersifat alamiah, dalam arti peneliti tidak berusaha memanipulasi seting penelitian, melainkan melakukan studi terhadap suatu fenomena. Alasan digunakannya metode deskriptif kualitatif untuk penelitian ini dikarenakan data deskriptif dapat dijelaskan secara mendetai dan mendalam. Data yang muncul dalam penelitian kualitatif ini berbentuk kata-kata, dan bukan rangkaian angka. Cara-cara yang digunakan peneliti untuk memperoleh data adalah dengan melakukan wawancara.

\section{SUBJEK PENELITIAN}

Subjek penelitian ini merupakan Perusahaan Graha Sukses Mandiri, sebuah perusahaan yang bergerak di bidang perdagangan bisnis dan pengembangan Sumber Daya Manusia di Tulungagung.

\section{METODE PENGUMPULAN DATA}

Metode pengumpulan data yang kami gunakan dalam penelitian ini adalah dengan melakukan wawancara dengan narasumber yang merupakan pihak dari perusahaan Graha Sukses Mandiri.

\section{METODE ANALISIS DATA}

Penelitian ini dilakukan dengan menggunakan metode analisis deskriptif kualitatif, yaitu dengan menganalisis, menggambarkan, dan meringkas berbagai kondisi, situasi dari berbagai data yang dikumpulkan berupa hasil wawacara atau pengamatan mengenai masalah yang diteliti yang terjadi di lapangan. ${ }^{9}$

\footnotetext{
${ }^{9}$ Moh. Shanminan (2014) Aziz, 'Perancangan Sistem Informasi Akuntansi Penjualan Dan Persediaan Pada Koperasi Mahasiswa UIN Maliki Malang', E-Theses Universitas Islam Negeri Maulana Malik Ibrahim., 2014, 7478 <http://etheses.uin-malang.ac.id/1960/>.
} 


\section{PEMBAHASAN}

\section{PROFIL SEJARAH PERUSAHAAN}

Perusahaan Asia Graha Sukses Mandiri Tulungagung bergerak di bidang perdangangan bisnis Directselling Offline. ATK (Alat Terapy Kesehatan) dan Pengembangan SDM tujuan memberikan peluang karir yang sebelumnya bernama WWI (World Wild Industries) berdiri pada tahun 1981 di Toronto Canada, dan didirikan oleh MR. MURRAY REINHART dan MR.LARRY TANEBAUM. Perusahaan ini berkembang pesat di seluruh dunia dan seluruh benua. Untuk mempermudah pengentrolan dan koordinasinnya maka di buatlah sub-sub organisasi yang berfungsi sebagai pengontrol di negara-negara tertentu disesuaikan dengan bidang usaha yang sedang di kembangkan di negara itu, salah satunnya Perusahaan Asia Graha Sukses Mandiri yang di dirikan pada tahun 1987 pleh MR.CHRIS NIARCHOS yang berpusat di UK (United Kingdom) Inggris.

Perkembangan PT.COBRA INTERNATIONAL begitu pesat di Inggris dan Australia, sehingga perusahaan ini melakukan ekspansi ke Asia termasuk Indonesia. Perusahaan ini masuk ke Indonesia pada akhir tahun 1994 dibawa oleh MR.TROY MOBBS (Australia) dibantu oleh rekannya MR.JHON RANKINK (Canada).

Sekarang di Indonesia berkembang lebih dari 200 anak perusahaan, salah satunya PT. Asia Graha Sukses Mandiri yang didirikan oleh Vice President di Indonesia yang bernama Bpk. T.A. HARIONO pada Januari 2006. Perusahaan ini meliputi 23 bidang usaha/divisi, diantaranya adalah: Advertising, Application, Charities, Credit, Sports, Product, Tes product, New Letter, Bulletin Telekomunication, Flayer, Clearence, dll.

\section{Di Indonesia saat ini telah berkembang 6 divisi, yaitu:}
a. Divisi Advertising
b. Divisi Flayer
c. Divisi Charities
d. Divisi Application
e. Divisi Clearence
f. Divisi Telecomunicat 


\section{Visi dan Misi PT Asia Graha Sukses Mandiri Tulungagung}

VISI:

a. Mengembangkan Sumber Daya Manusia (SDM) potensial

b. Perluas kantor (Expansi)

c. Management Training (karier dan non karier)

\section{MISI :}

a. Perluasan kantor di wilayah Indonesia dan wilayah tertentu di Indonesia

b. Pengangkatan staff ahli (Karyawan tetap/Non kontrak)

c. Pengangkatan kepala perusahaan (management/owner)

d. Orientasi management people/ orientasi SDM

\section{ASPEK TUJUAN KE LAPANGAN/VISI PRAKTEK SKILL SDM}

Tujuan ke lapangan adalah bagian dari aspek pengembangan skill Sumber Daya Manusia (SDM) sesuai arahan visi dan misi perusahaan. Tujuan tersebut meliputi 2 aspek:

a. Pengembangan kecakapan komunikasi/ meliputi skill komunikasi.

b. Pengembangan diri meliputi: Motivasi diri, Percaya diri, Mentalitas, Kepemimpinan dan Managerial

Sasaran yang ingin dicapai: Menuju staff hanya sampai staff ahli (telah memahami dan menguasai sistem-sistem perusahaan termasuk tugas-tugas sebagai seorang Staff), dan kepercayaan lanjut dari pihak management atas dasar pengembangan SDM menuju Karier (Assistant manager/ Manager/ Owner).

\section{KUALIFIKASI MANAGEMENT}

a Observasi: Orang yang baru mulai ikut untuk memahami ystem kerja perusahaan dan untuk mengetahui skill/ kemampuan yang dimilikinya.

b. Orientasi: Mengenal pembelajaran ystem perusahaan tentang teori dan praktek oleh supervisor anda masing-masing (5 Langkah komunikasi dan 8 Langkah menuju sukses).

c. Executive: Dapat memahami ystem 5 dan 8 langkah, sehingga bisa mengembangkan potensinya untuk menghandle media (sudah paham dan bisa menjalankan sendiri pembelajaran ystem yang ada).

d. Leader: Belajar kepemimpinan, baik memimpin diri sendiri atau memimpin orang lain (harus jadi contoh yang baik untuk orang lain).

e. Assistant Manager: Disini anda sudah mendapatkan penghasilan dari kantor $20 \%$ ditambah juga hasil prestasi anda sendiri (sudah dapatkan gaji tetap). 
f. Manager (Owner): Anda membiayai tanggungjawab umum dan tanggungjawab untuk mau menjalankan bisnis ini dengan sportifitas tinggi).

\section{BAGAN MANAGEMENT}

KARIR PT ASIA GRAHA SUKSES MANDIRI TULUNGAGUNG

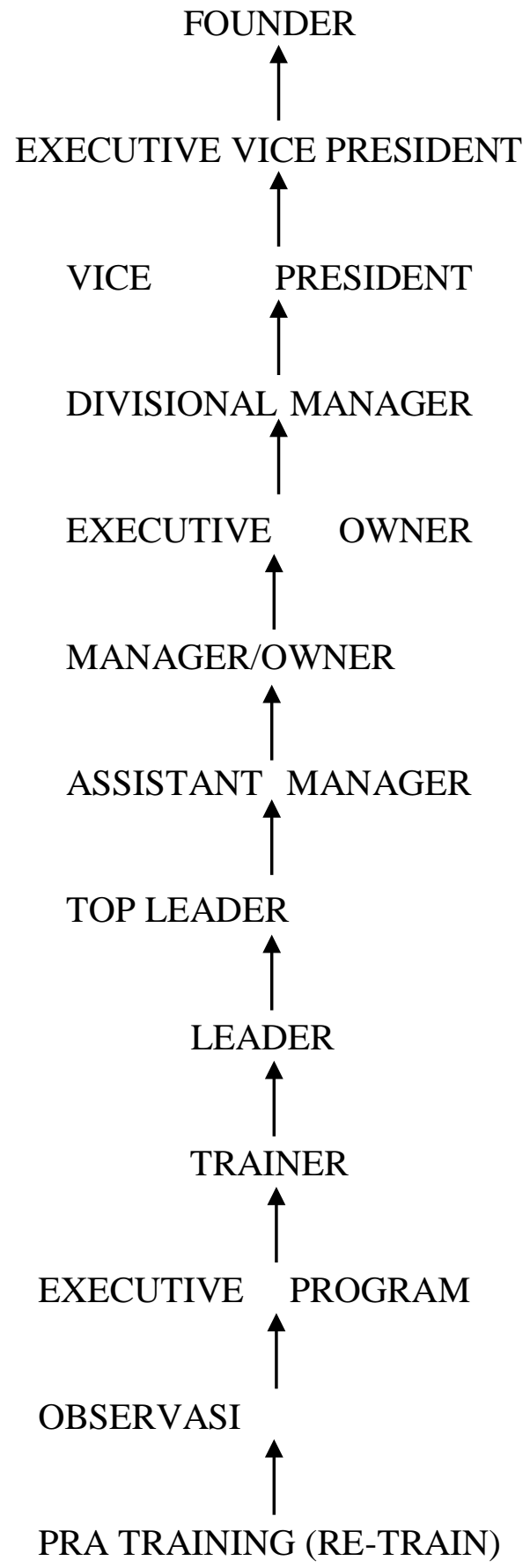


Pajak merupakan iuran atau kontribusi wajib yang dibayarkan masyarakat maupun suatu perusahaan kepada pemerintah untuk pembiayaan negara tanpa mendapat imbalan secara langsung. Apabila pendapatan pajak menurun, otomatis proses pembangunan negara tidak akan signifikan, namun jika perolehan suatu pajak meningkat maka proses pembangunan tersebut akan signifikan.

Membayar pajak merupakan kewajiban bagi setiap perusahaan namun terkadang perusahaan sering lalai menjalankan kewajibannya dalam membayar pajak dengan berbagai alasan, salah satunya tidak memiliki laporan keuangan sehingga perusahaan tidak dapat menentukan berapa besar jumlah pajak yang harus dibayarkan.

Dari sisi pemerintahan, pajak merupakan sumber utama dari pendapatan negara. Namun dari sisi perusahaan pajak merupakan beban yang akan mengurangi laba bersih dari suatu perusahaan. Meskipun saat ini masih banyak perusahaan yang tidak taat pajak dikarenakan dari berbagai hal, sebenarnya membayar pajak itu memiliki berbagai ragam manfaat. Seperti : Belajar mengelola keuangan, bisnis terlihat lebih professional, mampu menstabilkan kegiatan perekonomian, dll. Maka dari itu Perusahaan Asia Graha Sukses Mandiri Tulungagung secara tegas sangat menyikapi dan setuju dengan adanya pajak pertambahan nilai (PPN) dikarenakan adanya ketentuan dari pihak perusahaan pusat dan sudah distandarkan dengan aturan yang berlaku bagi perusahaan.

\section{MEMAHAMI TINGKAT KEDISIPLINAN PERUSAHAAN DALAM PEMBAYARAN PAJAK PERTAMBAHAN NILAI (PPN)}

Kesadaran dan kepedulian sukarela dari Wajib Pajak (WP) sangat sulit untuk diwujudkan seandainya dalam definisi 'Pajak' tidak ada frase yang dapat dipaksakan dan yang bersifat memaksa. Bertitik tolak dari fase ini menunjukkan membayar pajak bukan sematamata perbuatan sukarela atau karena suatu kesadaran. Frase ini memberikan suatu pemahaman dan pengertian bahwa masyarakat atau perusahaan dituntut untuk melaksanakan kewajiban kenegaraan dengan membayar pajak secara sukarela dan penuh kesadaran sebagai aktualisasi semangat gotong-royong atau solidaritas nasional untuk membagunan perekonomian nasional.

Sampai sekarang kesadaran masyarakat dalam membayar pajak masih belum mencapai tingkat sebagaimana yang diharapkan. Umumnya masyarakat masih sinis dan kurang percaya terhadap keberadaan pajak dikarenakan masih merasa seperti upeti, yang memberatkan pembayarannya, pembayarannya sering mengalami kesulitan, ketidakmengertian masyarakat apa dan bagaimana pajak dan kesulitan dalam menghitung dan melaporkannya. Namun masih ada upaya yang dapat dilakukan sehingga masyarakat sadar sepenuhnya untuk membayar pajak dan ini bukanlah sesuatu yag mustahil terjadi. Ketika masyarakat memiliki kesadaran maka membayar pajak akan dilakukan secara sukarela, bukan karena keterpaksaan.

Kesadaran membayar pajak ini tidak hanya memunculkan sikap patuh, taat dan disiplin semata tetapi diikuti sikap kritis juga. Semakin maju masyarakat dan pemerintahnya, maka semakin tinggi kesadaran untuk membayar pajak, namun tidak hanya berhenti sampai disitu justru mereka semakin kritis dalam menyikapi masalah perpajakan, terutama terhadap materi kebijakan di bidang perpajakannya, misalnya yaitu penerapan tarifnya, mekanisme pengenaan pajaknya, regulasinya, benturan praktek dilapangan, dan perluasan subjek dan objeknya.

Masyarakat di negara maju memang telah merasakan manfaat pajak yang mereka bayar. Bidang kesehatan, pendidikan, sosial maupun sarana dan prasarana transportasi yang cukup maju maupun biaya operasional aparat negara berasal dari pajak mereka. Pelayanan medis gratis, sekolah murah, jaminan sosial maupun alat-alat transportasi modern menjadi bukti 
pemerintah mengelola dana pajak dengan baik. Dengan adanya kesadaran pajak ini diharapkan Indonesia akan menuju kesejahteraan yang selama ini diharapkan.

\section{MENGETAHUI DAMPAK YANG TERJADI DI PERUSAHAAN DENGAN ADANYA PAJAK PERTAMBAHAN NILAI (PPN)}

Pajak merupakan suatu pemungutan yang dibayarkan oleh seluruh rakyat baik seara pribadi maupun secara badan usaha berpenghasilan kena pajak sesuai yang telah ditentukan. Pajak memiliki peranan penting bagi kemajuan penting bagi perekonomian suatu negara serta membawa pengaruh bagi perusahaan.

Berikut ini merupakan pengaruh pajak terhadap perusahaan $:^{10}$

\section{Mendorong perkembangan perusahaan}

Mengukuhkan perusahaan menjadi perusahaan kena pajak (PKP) adalah langkah awal yang bisa dilakukan oleh perusahaan untuk mendorong perusahaan tersebut menjadi lebih besar dan professional.

\section{Menentukan nilai akhir laba perusahaan}

Dalam perusahaan pengusaha seringkali mengidentifikasikan pajak sebagai beban. Pajak dianggap sebagai beban yang wajib dibayarkan oleh perusahaan. Dengan adanya pajak, pengusaha akan berusaha meminimalkan pajak yang dibayar agar apa yang diperoleh akan lebih optimal.

\section{Perusahaan melakukan perencanaan dan manajemen pajak}

Perencanaan pajak dan manajemen pajak biasanya dilakukan perusahaan sebagai salah satu cara untuk tetap memenuhi kewajiban pajaknya dengan baik. Pajak yang dibayarkan dapat ditekan serendah mungkin agar tetap memperoleh laba yang diinginkan. Cara tersebut dilakukan untuk memaksimalkan penghasilan setelah pajak agar perusahaan tetap untung.

\section{Reputasi perusahaan}

Perusahaan yang dalam seluruh kegiatannya kurang atau sering terlambat dalam membayar pajak dapat memperburuk citra perusahaan. Dengan lebih berhati-hati menyusun laporan keuangan perusahaan, dapat menjadi cara yang efektif untuk mengantisipasi hal tersebut. Selain itu, perusahaan juga bisa mencatat berbagai hal-hal penting dimana perusahaan harus setor atau lapor pajak.

\section{Mengetahui letak efisiensi perusahaan}

Perusahaan yang tidak kena pajak lebih berpotensi dalam mengalami pemborosan keuangan perusahaan. Hal ini terjadi karena perusahaan kurang mengkaji dan merencanakan keuangan perusahaannya dengan matang, termasuk perhitungan nilai akhir besar laba perusahaan. Dampak bagi perusahaan: perusahaan semakin menerapkan sistem kerja yang maksimal dan teratur dan hasil bisnis yang maksimal.

\footnotetext{
${ }^{10}$ klickpajak.com, 'Pengaruh Pajak Terhadap Perusahaan', 1386, $283<$ https://klikpajak.id/blog/beritapajak/pengaruh-pajak-terhadap-perusahaan/>.
} 


\section{MEMAHAMI MEKANISME PEMBAYARAN PAJAK PERTAMBAHAN NILAI (PPN) YANG DILAKUKAN PERUSAHAAN}

Pajak perusahaan bulanan wajib dibayarkan agar usaha yang dijalankan semakin melejit dan semakin kredibel di mata klien. Setelah mendirikan dan memperoleh perizinan memulai usaha atau bisnis, ada beberapa kewajiban perusahaan terkait dengan pajak yang harus dipatuhi. Umumnya, perusahaan hanya sibuk mengurus pajak pada masa-masa pelaporan SPT Tahunan. Padahal kewajiban tersebut ada yang harus dipenuhi bulanan dan tahunan.

Semua perusahaan baik itu berbentuk perusahaan perorangan, badan usaha, ataupun badan hukum, apabila telah memiliki NPWP maka sudah melekat kewajiban perpjakan pada perusahaan tersebut. Hal ini tercantum pada pasal 3 ayat 1 UU No. 6 Tahun 1983 tentang ketentuan umum dan tata cara perpajakan sebagaimana telah beberapa kali diubah terakhir dengan UU No. 16 Tahun 2009 yang menyatakan bahwa: "Setiap wajib pajak wajib mengisi surat pemberitahuan dengan benar, lengkap, dan jelas, dalam bahasa Indonesia dengan

menggunakan huruf latin, angka Arab, satuan mata uang rupiah, dan menandatangani serta menyampaikannya ke Kantor Direktorat Jenderal Pajak tempat wajib pajak terdaftar atau dikukuhkan atau tempat lain yang ditetapkan oleh direktur Jendral Pajak.”

Dalam pelaksanaan kewajiban perpajakan, pemerintah telah memberikan kepercayaan kepada wajib pajak baik perusahaan maupun perorangan untuk menghitung, menyetor, dan melporkan pajak secara mandiri atau yang biasa dikenal dengan istilah "Self-Assesment System". Walaupun wajib pajak perusahaan diberkan kepercayaan oleh kantor pajak untuk melaksanakan kewajiban perpajakannya secara mandiri, namun jangan disalahgunakan, karena akan mendapat sanksi yang berat. Pasal 13A UU No. 6 Tahun 1983 menyatakan bahwa: "Wajib pajak yang karena kealphaannya tidak menyampaikan surat pemberitahuan atau menyampaikan surat pemberitahuan, tetapi isinya tidak benar atau tidak lengkap, atau melampirkan keterangan yag isinya tidak benar sehingga menimbulkan kerugian pada pendapatan negara, tidak dikenai sanksi pidana apabila kealphaan tersebut pertama kali dilakukan oleh wajib pajak dan wajib pajak tersebut diwajibkan untuk melunasi kekurangan jumlah kekurangan pajak yang terutang beserta sanksi administrasi berupa kenaikan sebesar $200 \%$ dari jumlah pajak yang kurang dibayar,yang ditetapkan melalui penerbitan Surat Ketetapan Pajak Kurang Bayar (SKPKB)." "11

${ }^{11} \mathrm{Https}$ //www.easybiz.id/, 'Pajak Perusahaan Yang Harus Dipenuhi Tiap Bulan Saat Menjalankan Bisnis', 2009, 1983 <https://www.easybiz.id/pajak-perusahaan-tiap-bulan/>. 



\section{HASIL PENELITIAN}

Peneliti melakukan metode deskriptif kualitatif yaitu dengan melakukan wawancara, serta melakukan observasi dan mengambil dokumentasi untuk mengetahui bagaimana pendapat masyarakat maupun perusahaan tentang adanya pajak pertambahan nilai, bagaimana tingkat kedisiplinan masyarakat maupun perusahaan dalam membayar pajak, dan bagaimana dampak dari adanya pajak pertambahan nilai (PPN).

Peneliti melakukan wawancara dengan salah satu peserta traineer, yaitu Sdr. Apoli Benediktus Yahya dalam kaitannya dengan bagaimana saja pendapat-pendapat dari adanya Pajak Pertambahan Nilai (PPN). Responden menyatakan bahwa :

"Eksistensi tentang adanya pajak pertambahan nilai (PPN) di perusahaan Asia Graha Sukses Mandiri Tulungagung ini rupanya sangat mempengaruhi kinerja dari perusahaan tersebut, yang dimana perusahaan akan semakin menerapkan sistem kerja yang maksimal dan teratur sehingga menjadikan tingkat penjualan dapat mencapai target yang diharapkan".

Seiring dengan adanya pajak pertambahan nilai (PPN) yang harus dibayarkan baik masyarakat maupun perusahan, keduanya memberikan suatu pernyataan bahwa: "Adanya pajak pertambahan nilai (PPN) ini mampu berdampak kepada perkembangan dalam suatu bisnis maupun perusahaan. Yaitu: mampu mendorong perkembangan kinerja perusahaan, menentukan nilai akhir dari laba perusahaan, menjaga reputasi perusahaan, dan perusahaan akan melakukan suatu perencanaan dan manajemen pajak. 


\section{PENUTUP}

\section{Kesimpulan}

Pemahaman dan kesadaran masyarakat maupun perusahaan yang melakukan transaksi pajak dalam pemenuhan kewajiban pajak penghasilan masih kurang yang mana meskipun mengetahui bahwa penghasilan yang diperoleh melalui transaksi pajak merupakan objek pajak, tetap saja baik masyarakat dan perusahaan tersebut tidak mendaftarkan diri untuk mendapatkan NPWP, melaksanakan kewajiban pemenuhan pajaknya dengan tidak memasukkan penghasilan dari transaksi pajak yang dilakukan ke dalam SPT tahunannya. Bahkan ada perusahaan yag tidak mengetahui transaksi pajak yang dilakukannya itu dikenai pajak penghasilan.

Wajib pajak sendiri selayaknya memahami pentingnya pemenuhan pajak penghasilannya, karena pajak yang dibayarkan oleh wajib pajak akan digunakan sebagai biaya bagi pembangunan nasional yag dilakukan oleh pemerintah, maka wajib pajak harus memenuhi pajak dalam setiap tahun 


\section{DAFTAR PUSTAKA}

Aziz, Moh. Shanminan (2014), 'Perancangan Sistem Informasi Akuntansi Penjualan Dan Persediaan Pada Koperasi Mahasiswa UIN Maliki Malang', E-Theses Universitas Islam Negeri Maulana Malik Ibrahim., 2014, 74-78 <http://etheses.uin-malang.ac.id/1960/>

Brotodiharjo, ‘Perhitungan PPn', Wandha Mar.8 (1991)

Fatoni, Irfan, and Indah Dewi Nurhayati, 'Jurnal Manajemen Dan Akuntansi Volume 3, Nomor 2, Agustus 2014', 3.April (2014), 1-14

Https://www.easybiz.id/, 'Pajak Perusahaan Yang Harus Dipenuhi Tiap Bulan Saat Menjalankan Bisnis', 2009, 1983 <https://www.easybiz.id/pajak-perusahaan-tiap-bulan/>

klickpajak.com, 'Pengaruh Pajak Terhadap Perusahaan', 1386, 283

<https://klikpajak.id/blog/berita-pajak/pengaruh-pajak-terhadap-perusahaan/>

Prabowo, Rachmad Gesah Mukti, 'MEKANISME PPN DAN PPnBM', 2019 <https://doi.org/10.31227/osf.io/shqmg>

Rafinzka, Kezia, 'Pasal 4 UU PPN', Angewandte Chemie International Edition, 6(11), 951952., 42, 1967, 3-4 <https://www.online-pajak.com/tentang-ppn-efaktur/pasal-4-uu-ppn> 